\title{
A Facility to Remotely Assemble Radioisotope Thermoelectric Generators
}

\author{
J. W. Engstrom \\ L. H. Goldmann \\ R. W. Truitt
}

Date Published

July 1992

To Be Presented at 10 th Symposium on Space Nuclear Power and Propulsion Albuquerque, New Mexico January $10-14,1993$

Prepared for the U.S. Department of Energy

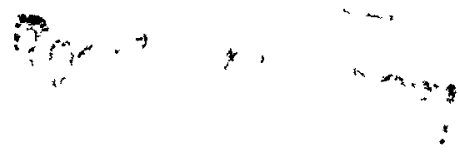
Assistant Secretary for Nuclear Energy

Hanford Operations and Engineering Contractor for the US. Department of Energy under Contract DE-AC06-87RL10930

Copyright License By acceptance of this andele, the publisher and/or recipient acknowledges the U S Government's nght to retain a nonexclusive, royaky-tree license in and to any copyright covering this paper. 


\section{DISCLAIMER}

This report was prepared as an account of work sponsored by an agency of the United States Government. Neither the United States Government nor any agency Thereof, nor any of their employees, makes any warranty, express or implied, or assumes any legal liability or responsibility for the accuracy, completeness, or usefulness of any information, apparatus, product, or process disclosed, or represents that its use would not infringe privately owned rights. Reference herein to any specific commercial product, process, or service by trade name, trademark, manufacturer, or otherwise does not necessarily constitute or imply its endorsement, recommendation, or favoring by the United States Government or any agency thereof. The views and opinions of authors expressed herein do not necessarily state or reflect those of the United States Government or any agency thereof. 


\section{DISCLAIMER}

Portions of this document may be illegible in electronic image products. Images are produced from the best available original document. 


\section{LEGAL DISCLAIMER}

This report was prepared as an account of work sponsored by an agency of the United Siates Government. Neither the United States Government nor any agency thereof, nor any of their employees, nor any of their contractors, subcontractors or their employees, makes any warranty, express or implied, or assumes any legal liability or responsibility for the accuracy, completeness, or any third party's use or the results of such use of any information, apparalus, product, or process disclosed, or represents that its use would not infringe privately owned rights. Reference herein to any specilic commercial product, process, or service by trado name, trademark, manufacturer, or otherwise, does not necessarily constitute or imply its endorsement, recommendation, or favoring by the United States Government or any agency thereof or its contractors or subcontractors. The views and opinions of authors expressed herein do not necessarily state or reflect those of the United States Government or any agency thereol.

This report has been reproduced from the best available copy.

Prinled in the Uniled States of America

DISCLM-2.CHP (1-91) 


\title{
A FACILITY TO REMOTELY ASSEMBLE RADIOISOTOPE THERMOELECTRIC GENERATORS
}

\author{
John W. Engstrom \\ Louis H. Goldmann \\ Ross W. Truitt \\ Westinghouse Hanford Company \\ P.O. Box 1970 \\ Mail Stop N1-42 \\ Richland, WA 99352
}

(509) 376-8290

\begin{abstract}
Radioisotope Thermoelectric Generators (RTGs) are electrical power sources that use heat from decaying radioisotopes to directly generate electrical power. The RTG assembly process is performed in an inert atmosphere inside a large glovebox, which is surrounded by radiation shielding to reduce exposure to neutron and gamma radiation from the radioisotope heat source. In the past, allowable dose rate limits have allowed direct, manual assembly methods; however, current dose rate limits require a thicker radiation shielding that makes direct, manual assembly infeasible.

To minimize RTG assembly process modifications, telerobotic systems are being investigated to perform remote assembly tasks. Telerobotic systems duplicate human arm motion and incorporate force feedback sensitivity to handle objects and tools in a human-like manner. A telerobotic system with two arms and a threedimensional (3-D) vision system can be used to perform remote RTG assembly tasks inside gloveboxes and cells using unmodified, normal hand tools.
\end{abstract}

\section{INTRODUCTION}

Westinghouse Hanford Company (Westinghouse Hanford) is installing the Radioisotope Power Systems Facility (RPSF) in the Fuels and Materials Examination Facility (FMEF) at the Hanford Site in southeastern Washington State. The RPSF will be used to assemble and test RTGs (Carteret 1992). The purpose of the project is to build a modern production facility that meets current environmental, safety, and health standards. This new facility is being built to replace U.S. Department of Energy (DOE) facilities at Mound Laboratories in Ohio. The design status of several RPSF systems has been previously presented (Alderman 1992; Adkins and Williams 1992).

The RTGs assembled for space applications produce approximately $300 \mathrm{We}$ and have been used to power electronic equipment aboard deep space probes. The heat source inside these RTGs consists of 18 General Purpose Heat Source (GPHS) modules that have a thermal output of 4,500 Wt. The decay heat from the GPHS modules is converted directly to electrical energy using a thermoelectric conversion process. Recent spacecraft deployment of RTGs includes "Galileo" (a Jupiter flyby mission) and "Ulysses" (a sun orbit mission). Each of these spacecraft carries two RTGs.

As shown in Figure 1, the RTG is cylindrical in shape with protruding radial fins. The RTG is about $42.7 \mathrm{~cm}$ (16.8 in.) in diameter by $113.0 \mathrm{~cm}(44.5 \mathrm{in}$.) in length and weighs about $55.8 \mathrm{~kg}(123 \mathrm{lb})$. The RTG has two major components, the heat source, which consists of a stack of 18 GPHS modules, and the thermoelectric converter. The thermoelectric converter is a cylindrical shell with radial fins for heat dissipation. The heat source support frames and support structure for the thermoelectric elements are mounted inside the shell. The heat source support frame and the midspan support plate hold the GPHS stack firmly in place, which enables the RTG to withstand the launch and ascent loads developed aboard the launch vehicle. In addition, each GPHS 


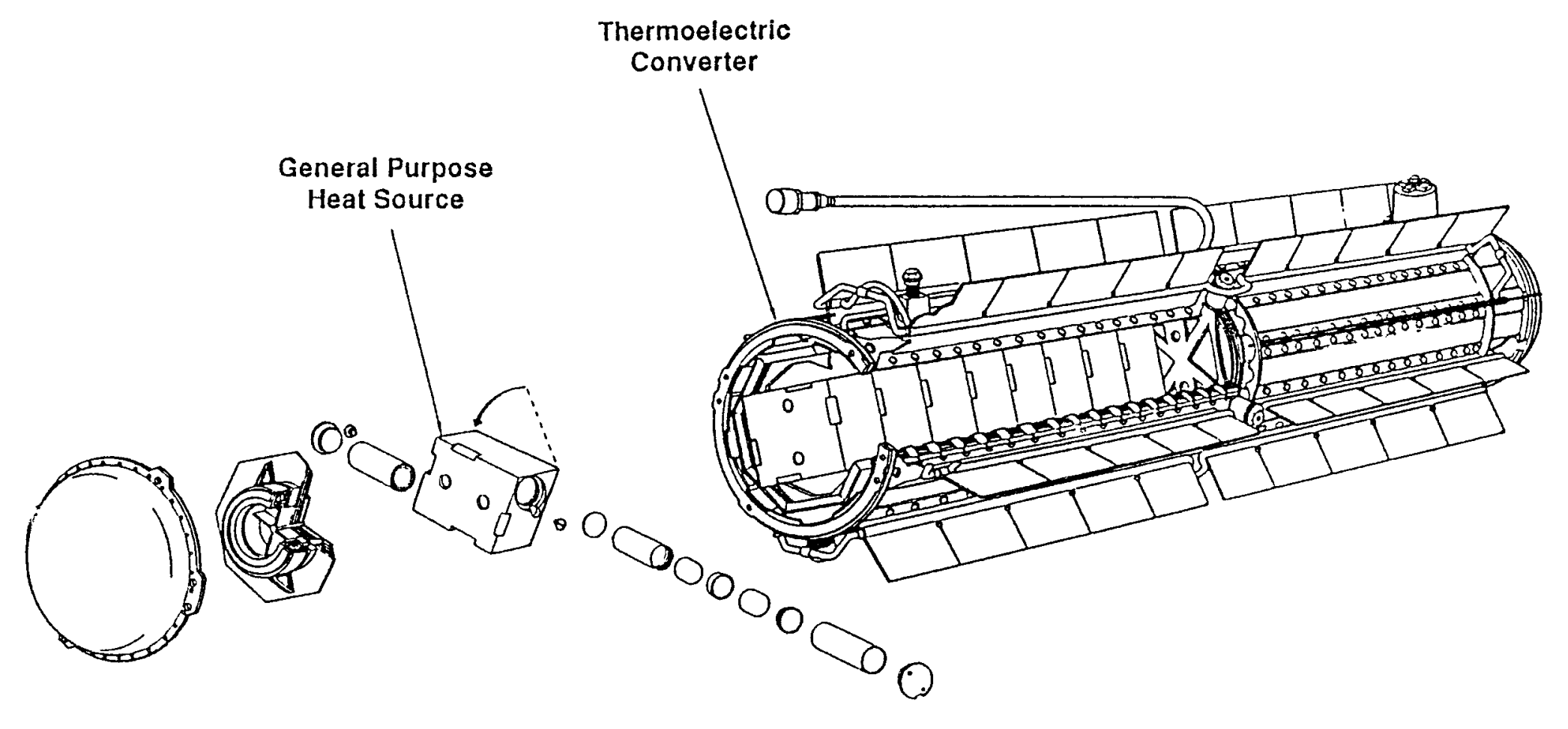


module is interlocked with circular locking members that prevent the modules from shifting laterally, but will allow the modules to freely separate during accidental reentry into the atmosphere. The RTG is equipped with four resistance temperature devices (RTDs) that monitor generator case temperature and provide an alert signal to take corrective action if a high-temperature condition occurs.

\section{DESCRIPTION}

\section{Assembly Process}

The RTG assembly process in the RPSF involves loading the thermoelectric converter with the GPHS modules. The thermoelectric converter is assembled by the converter manufacturer before delivery to the RPSF.

The RTGs are loaded with the GPHS modules inside an Inert Atmosphere Assembly Chamber (IAAC) to protect the thermoelectric components from oxidation. At present, RTGs are manually assembled in the IAAC, which presents a radiation dose hazard that exceeds current dose limit requirements.

In the IAAC, the RTG assembly process primarily involves stacking 18 GPHS modules into two "9-packs" and inserting the upper and lower "9-packs" into the thermoelectric converter. Special fixtures are used to stack the modules and handle the "9-packs" while being inserted into the converter. Presently, the stacking process is performed using master-slave manipulators with some manual assistance using gloves. After the GPHS modules are installed, the GPHS modules are preloaded at the midspan support plate. This preload adjustment requires tedious manual measurements and adjustments that are presently performed using gloves and hand tools. The GPHS modules are also preloaded in the axial direction using a manually operated preload fixture. The final components to be installed are a metal seal and dome, which closes the converter. The dome is fastened to the converter using 24 \#8 screws. The dome installation is performed manually through a glove port. At present, minimal shielding is provided at the glove ports and any increase in shielding thickness at the glove ports will restrict the worker's reach, hence the requirement for remote assembly techniques.

\section{Radiological Design}

The DOE has proposed new dose rate limits to reduce total exposure from an annual limit of 5.0 rem to a recommended annual total of $0.5 \mathrm{rem}$. The heat source material produces neutron radiation and gamma radiation from plutonium-236 $\left({ }^{236} \mathrm{Pu}\right)$ derived impurities. Under the previous requirements, direct manual assembly operations were allowable. Now, for design purposes, the ${ }^{236} \mathrm{Pu}$ impurity's age has increased to $18 \mathrm{yr}$ and the material's neutron quality factor has doubled. This change in criteria doubles the neutron dose rate and considerably increases the gamma dose rate. The to al dose rate has increased significantly, while the allowable dose rate limit has been considerably reduced, thereby making manual RTG assembly operations impermissible to perform. This also dictates a fully remote assembly process.

The new Westinghouse Hanford radiological design requirements are as follows:

\begin{tabular}{lccc}
\multicolumn{1}{r}{ Occupancy } & $\frac{\text { Design goal }}{(\mathrm{mrem} / \mathrm{h})}$ & & $\frac{\text { Maximum dose }}{(\mathrm{mrem} / \mathrm{h})}$ \\
Full time & 0.2 & & 0.5 \\
$<1 \mathrm{~h} / \mathrm{d}$ & 2.0 & 5.0 \\
$<1 \mathrm{~h} / \mathrm{wk}$ & 10.0 & 20.0 \\
$<10 \mathrm{~h} / \mathrm{yr}$ & 50.0 & 100.0 \\
No normal access & $>100.0$ & -
\end{tabular}


By fueling the RTG with ${ }^{28} \mathrm{Pu}$ that has more ${ }^{236} \mathrm{Pu}$ impurity and that has aged longer from the time of processing, the dose to the assembly technician increases 10 times and substantially exceeds the full-time occupancy design goal. The dose rate at the glove port window for this material is calculated to be $20 \mathrm{mrem} / \mathrm{h}$, which means the assembly technician can only work on the RTG assembly process less than $1 \mathrm{~h} / \mathrm{wk}$. This dose rate is not acceptable because it takes approximately 2 to 3 weeks to completely assemble an RTG. Therefore, remote assembly techniques are required to perform the assembly operations in order to reduce the dose rate to technicians.

\section{DISCUSSION}

Special fixtures and a large number of common hand tools are used during RTG assembly operations. If the existing master-slave manipulators are used to assemble the RTG remotely, existing tools will have to be modified considerably or new tools will have to be designed. This is because master-slave manipulators generally have limited dexterity and gripping capability.

In searching for remote methods to perform the existing assembly operations, it became apparent that a stateof-the-art telerobotic system, with its human-like dexterity, could be used with the existing assembly process. Given the dexterity of current telerobotic arms, modification of existing assembly tools and fixtures will be minimal or not required at all. Using two telerobotic arms and a torso will give full, human capability to perform the remote assembly tasks. Two important features that allow the telerobotic system to perform tasks remotely are its force feedback and position feedback capabilities. Force feedback provides the system with sensitivity and is important in distinguishing between hard and soft objects and in assembly operations such as threading fasteners. Because a telerobotic system is anthropomorphic (human-like), training in the use of the telerobotic arm is less than that required for the traditional master-slave manipulator because the motions and operations are as normal as working directly on the assembly and operations that require normal hand tools can be easily performed.

Figure 2 is a flow chart showing the steps used for the evaluation of a proposed remote telerobotic system. The tasks are shown consecutively for simplicity; however, in actual practice several tasks may be performed at the same time. Generally, tasks are completed in the order shown. This strategy was used during the evaluation of remote assembly techniques for the RTG assembly process.

The present RTG assembly process, which involves traditional hands-on and master-slave manipulator operations, typically exposes the assembly technicians to dose rates of 10 to $20 \mathrm{mrem} / \mathrm{h}$. Current regulations prohibit exposure to this dose rate for an extended time. In comparison, the proposed remote RTG assembly process would expose the technician to dose rates of 0.2 to $0.5 \mathrm{mrem} / \mathrm{h}$. This $1-1 / 2$ magnitude dose-rate reduction puts the proposed remote assembly operations securely in the "allowable" dose-rate range under current regulations.

Based on an all new facility, much of the cost increases attributed to a telerobotic system are partially of fiset by the simpler and less costly assembly area facilities needed to support the telerobotic system. Preliminary cost estimates show that in all new facilities, a telerobotic system used in a windowless concrete assembly cell would cost about one-third more than the traditional buildup assembly chamber with shielding windows in a large room.

The envisioned telerobotic system for remote RTG assembly operations would include a high-resolution, 3-D vision system for operator feedback. The vision system would be incorporated into a helmet that the assembly technician would wear while operating the two telerobotic arms. This arrangement gives the technician the most natural method for remote operation. An additional 3-D monitor system would be used by other personnel to oversee RTG assembly operations. The 3-D video signal could be adapted for complete hands-free operations by including text-based procedural assembly steps, as well as assembly cell process condition information. 


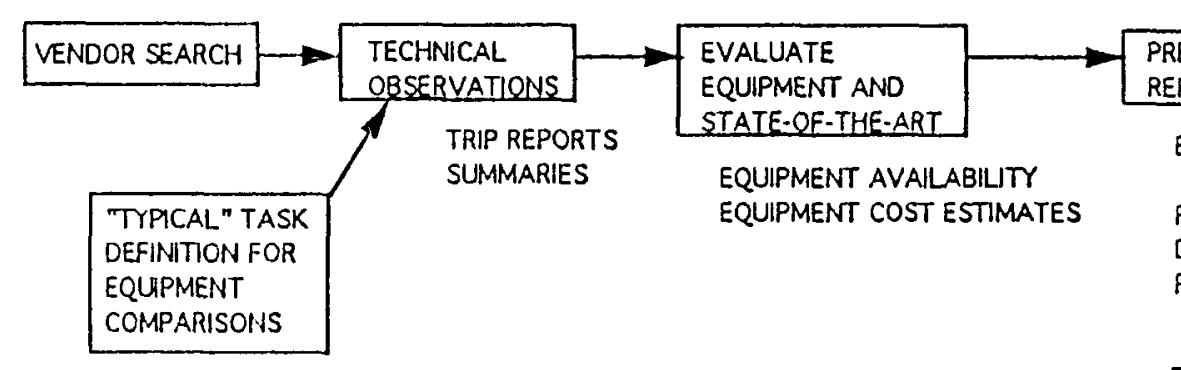

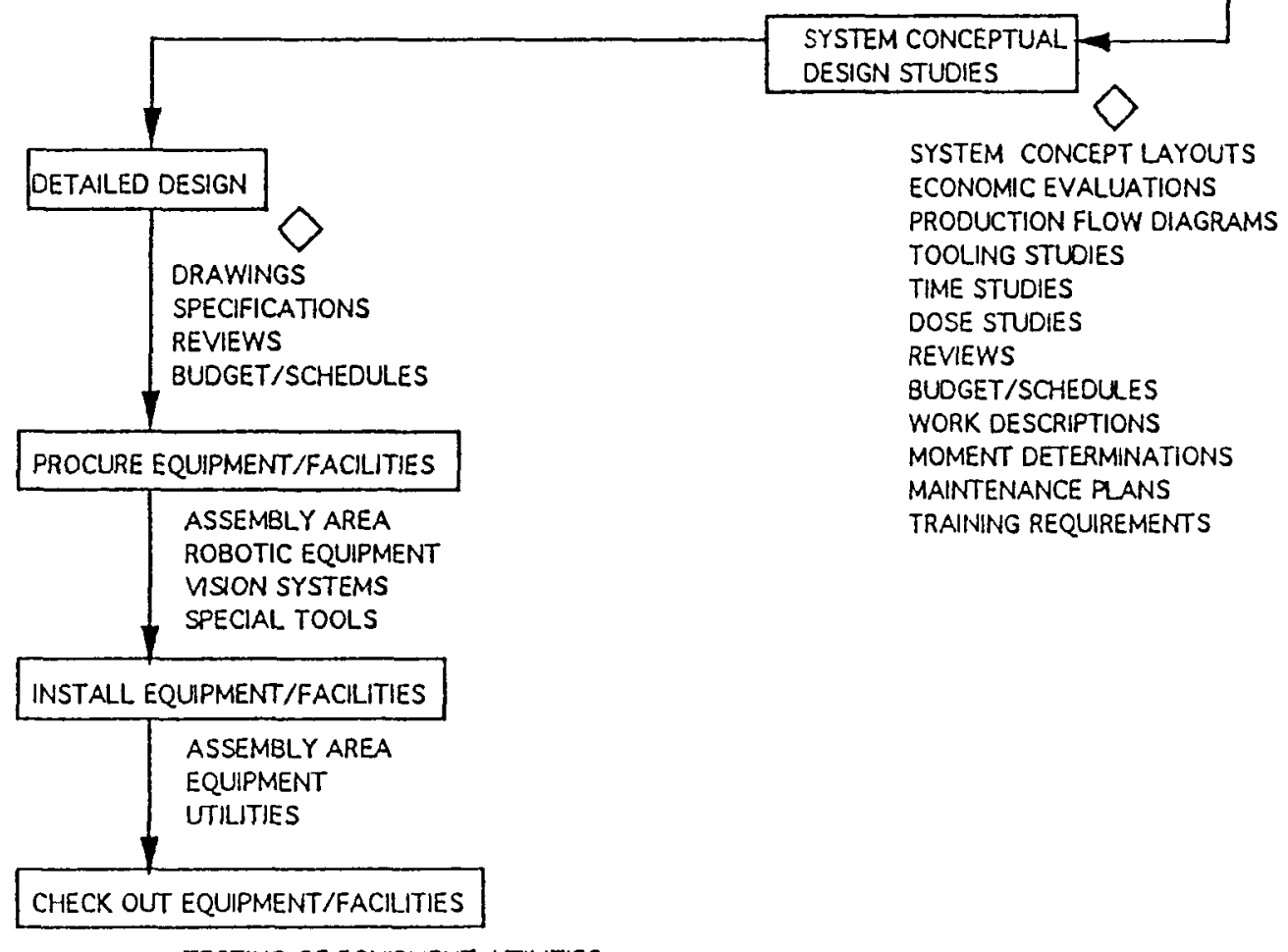

TESTING OF EQUIPMENT, UTIUTIES 
The proposed telerobotic system will also be capable of autonomous control for any future repetitive operation requirements. All motions and load-cell measurements can be recorded and logged for historical purposes and performance of repetitive motions. All telerobotic system controls and adjustments will be easily accessible by the assembly technician through a dedicated operator interface.

\section{CONCLUSIONS}

Installation of a telerobotic system will substantially reduce or eliminate radiation dose exposure to assembly technicians. Dose exposure limits have been reduced such that direct, manual assembly of RTGs is impossible because of the increased shielding thickness that is required. Telerobotic systems can allow a remote, human operator to work directly on tasks inside gloveboxes and hot cells.

There are many other applications for telerobotic systems in the areas of waste processing, decontamination and decommissioning, and processing of toxic nuclear and nonnuclear materials. Future work is planned to develop the process and equipment for these applications using telerobotic systems to remotely perform these tasks.

\section{ACKNOWLEDGEMENTS}

This work was performed by the Westinghouse Hanford Company under the DOE Contract No.

DE-AC06-87RL10930. This study was conducted by the Isotope Applications Group.

\section{REFERENCES}

Adkins, H. E. and J. A. Williams, 1992, Design and Equipment Installation for Radioisotope Power Systems Facility Metallic Cleaning Room 162 Subsystem 6130, AIP Conference Proceedings 246, Ninth Symposium, Space Nuclear Power Systems, M. S. El-Genk and M. D. Hoover (ed.), University of New Mexico, Albuquerque, New Mexico.

Alderman, C. J., 1992, Transport and Handling of Radioisotope Thermoelectric Generators at the Westinghouse Hanford Company, AIP Conference Proceedings 246, Ninth Symposium Space Nuclear Power Systems, M. S. El-Genk and M. D. Hoover (ed.), University of New Mexico, Albuquerque, New Mexico.

Carteret, B. A., 1992, Modification of Hot Cells for General Purpose Heat Source Assembly at the Radioisotope Power Systems Facility, AIP Conference Proceedings 246, Ninth Symposium Space Nuclear Power Systems, M. S. El-Genk and M. D. Hoover (ed.), University of New Mexico, Albuquerque, New Mexico. 
WHC-SA-1592-FP

DISTRIBUTION

Number of copies

ONSITE

Westinghouse Hanford Company

J. W. Engstrom N1-42

L. H. Goldmann

$\mathrm{N} 1-42$

R. W. Truitt

$\mathrm{N} 1-42$

Document Processing

and Distribution (2)

L8-15

Information Release

Administration

L8-07 